Global Conferences Series:

Social Sciences, Education and Humanities (GCSSSEH), Volume 6, 2020

International Conference Fakultas Tarbiyah dan Keguruan Universitas Islam Negeri Imam Bonjol Padang (ICFTKUINIBP) 2020

DOI: https://doi.org/10.32698/icft408

\title{
Improve Students' Mathematics Achievement Using Cooperative Learning: Number Head Together
}

\section{Peningkatan Hasil Belajar Matematika Siswa Menggunakan Model Pembelajaran Kooperatif Teknik Kepala Bernomor}

\author{
Rabiati $^{\mathrm{a}}$, Fitria Mardika ${ }^{\mathrm{b}}$, Nita Putri Utami ${ }^{\mathrm{b}}$ \\ ${ }^{a}$ Sekolah Menengah Atas Negeri 10 Pekanbaru, Indonesia, ${ }^{b}$ Universitas Islam Negeri Imam Bonjol, Padang, \\ Indonesia \\ E-mail: fitriamardika@uinib.ac.id
}

\begin{abstract}
This action research aims to improve students' mathematics achievement using Number Head Together in Cooperative Learning. The subjects were students of X.5 Class at SMAN 10 Pekanbaru in 2015/2016. The model was implemented in two cycles. Data were collected through mathematics test, observation sheets on learning process and questionnaire. Data were analysed through quantitative and qualitative analysis. In the first cycle, students mathematics achievement improve to 52,5\%. In the second cycle, students mathematics achievement improve to $77,5 \%$. It satisfied the criteria for successful action of this research. To sum up, it can be conclude that number head together in cooperative learning can be alternative modal that can be implemented to improve students' mathematics achievement.
\end{abstract}

Keywords: Cooperative learning, number head together, students' mathematics achievement

\section{PENDAHULUAN}

Hasil belajar merupakan salah satu tolak ukur ketercapaian tujuan pembelajaran dan dapat diidentifikasikan sebagai prestasi yang diperoleh siswa setelah melewati suatu proses pembelajaran. Hasil belajar dapat didefinisikan sebagai kompetensi dan keterampilan yang dimiliki siswa setelah melewati suatu proses pembelajaran (Molstad \& Karseth, 2016). Warsita (2008) mengatakan bahwa salah satu tanda sesorang telah belajar adalah adanya perubahan tingkah laku dalam dirinya.

Sejalan dengan itu, maka dapat dikatakan bahwa hasil belajar matematika adalah kompetensi dan keterampilan yang dimiliki siswa setelah melalui proses pembelajaran matematika. Di Indonesia, tolak ukur keberhasilan proses pembelajaran adalah ketika siswa telah melewati nilai Kriteria Ketuntasan Minimum (KKM) yang telah ditetapkan. Pada kurikulum 2013, KKM meliputi aspek kognitif, afektif, dan psikomotor.Idealnya setiap siswa harus memperoleh hasil yang baik untuk ketiga aspek ini.

Guru sebagai fasilitator harus memastikan proses pembelajaran memungkinkan siswa untuk memperoleh hasil belajar yang baik. Guru secara langsung mempengaruhi, membina dan mengembangkan kemampuan siswa agar menjadi manusia cerdas, terampil dan bermodal tinggi. Rusman (2012) dalam sistem pembelajaran guru dituntut untuk mampu memilih metode pembelajaranyang tepat. Oleh karena itu, proses pembelajaran harus sesuai dengan kebutuhan materi yang diajarkan, kondisi siswa, serta factor-faktor lainnya. Guru juga harus mampu mengembangkan keterampilan-keterampilan dalam proses pembelajaran guna meningkatkan mutu dan prestasi belajar siswa.Slameto (2003) mengatakan seorang guru diharapkan dapat merencanakan pembelajaran sebaik mungkin, seefektif mungkin agar apa yang menjadi tujuan dalam pembelajaran dapat tercapai dengan baik.

Berdasarkan hasil pengamatan pada siswa kelas X.5 SMAN 10 Pekanbaru, diketahui bahwa hasil belajar matematika pada tahun pelajaran 2015/2016 belum sesuai dengan harapan.Sebagian besar siswa

Copyright $@ 2020$, the Authors. Published by Redwhite Press.

Page | 104

This is an open access article under the CC BY-NC license

(http://creativecommons.org/licenses/by-nc/4.0). 
belum mencapai KKM yang ditetapkan, yaitu 78. Hal ini dapat dilihat dari persentase ketercapaian KKM ulangan harian 40 siswa pada semester ganjil tahun pelajaran 2015/2016, yaitu $60 \%$ siswa tidak mencapai KKM atau sebanyak 24 siswa.

Beberapa masalah yang timbul dalam proses pembelajaran, diantaranya siswa masih kurang berpartisipasi dalam proses pembelajaran, siswa juga enggan untuk mengerjakan tugas secara mandiri, dan siswa lebih memilih bertanya kepada teman atau menyalin jawaban teman. Guru pernah membentuk kelompok belajar siswa berdasarkan tempat duduk siswa, namun dalam pelaksanaannya hanya beberapa siswa saja yang aktif mengerjakan tugas, yaitu siswa yang berkemampuan tinggi. Sedangkan siswa lainnya hanya menyalin pekerjaan temannya tanpa menggali informasi tentang materi yang dipelajari.

Peneliti melakukan observasi(mengamati aktivitas guru dan siswa selama proses pembelajaran berlangsung). Dari hasil pengamatan didapatkan bahwa pada kegiatan pendahuluan guru membuka pembelajaran dengan menyiapkan siswa, mengabsen siswa, dan menanyakan tentang pekerjaan rumah yang telah diberikan pada pertemuan sebelumnya.Kemudian, guru meminta siswa mengumpulkan dan membahas pekerjaan rumah tersebut di papan tulis. Terlihat bahwa guru hanya memfokuskan perhatian siswa dengan pekerjaan rumah yang telah diberikan tanpa menanyakan apakah siswa telah siap untuk mengikuti proses pembelajaran pada hari itu.

Dari hasil wawancara dengan beberapa perwakilan siswa diperoleh informasi bahwa siswa tidak memahami dengan baik penjelasan dari guru.Siswa pernah melakukan pembelajaran secara berkelompok.Namun pada prosesnya siswa hanya diberikan tugas berupa soal-soal pada buku paket siswa untuk dikerjakan bersama-sama didalam kelompok.

Sehubungan dengan masalah tersebut, proses pembelajaran yang telah dilaksanakan dinilai belum bisa mengaktifkan siswa secara optimal untuk memahami konsep dan mendorong siswa untuk mengkonstruksikan pengetahuan yang mereka miliki untuk menyelesaikan soal. Proses pembelajaran tersebut juga belum bisa melibatkan siswa secara aktif dalam kegiatan belajar mengajar dan mendorong siswa berinteraksi serta berkomunikasi secara efektif.

Untuk mengatasi masalah proses pembelajaran matematika tersebut, peneliti mencoba model pembelajaran yang dapat mengaktifkan pertukaran pengetahuan antara siswa yang satu dengan lainnya sehingga siswa menjadi bersemangat untuk mengerjakan soal-soal serta mempunyai rasa tanggung jawab dengan tugasnya. Mode pembelajaran tersebut adalah model pembelajaran kooperatif .Pembelajaran kooperatif merupakan bentuk perubahan pola pikir dalam kegiatan belajar mengajar di sekolah. Guru tidak lagi mendominasi kegiatan pembelajaran. Guru lebih banyak menjadi fasilitator dan mediator dari proses pembelajaran. Model Pembelajaran Kooperatif dirancang dengan memberikan kesempatan kepada siswa secara bersama-sama untuk membangun pengetahuannya sendiri.Tujuan dibentuknya kelompok tersebut adalah untuk memberikan kesempatan kepada semua siswa untuk dapat terlibat aktif dalam proses berpikir dan kegiatan belajar. Selama bekerja dalam kelompok, tugas anggota kelompok adalah mencapai ketuntasan materi yang disajikan oleh guru, dan saling membantu teman sekelompoknya untuk mencapai ketuntasan belajar (Trianto, 2007)

Pembelajaran Kooperatif yang mampu meningkatkan rasa tanggung jawab pribadi siswa terhadap kelompoknya adalah model pembelajaran kooperatif yang dapat meningkatkan rasa tanggung jawab pribadi siswa terhadap kelompoknya adalah Pembelajaran Kooperatif Teknik Kepala Bernomor.Pembelajaran teknik Kepala Bernomormemberikan kesempatan kepada siswa untuk saling membagikan ide-ide, mempertimbangkan jawaban yang paling tepat, mendorong siswa untuk lebih bertanggung jawab dalam mengerjakan tugas dan meningkatkan semangat kerjasama mereka. Dalam penerapannya, masing-masing siswa dalam kelompok akan diberikan nomor yang berbeda. Pemberian nomor ini bertujuan untuk mempermudah dalam menentukan siapa yang akan menjadi perwakilan kelompok untuk mempresentasikan hasil kerja kelompoknya dan juga memastikan keterlibatan total dari semua siswa (Lie, 2010 \& Slavin, 1995).

Melalui pembelajaran kooperatif teknik kepala bernomor masing-masing siswa dikelompokkan dan diberi nomor identitas dan nama kelompok. Setiap siswa bertanggung jawab untuk dapat memahami materi pembelajaran (Arends \& Kilcher, 2010). Setiap siswa harus saling memastikan bahwa anggota kelompoknya memahami jawaban dari setiap permasalahan yang diberikan guru dan mampu untuk mempresentasikannya.Ketika salah seorang siswa dipanggil untuk mempresentasikan, siswa lain diberikan kesempatan untuk memberikan tanggapan atau pendapatnya.

Berdasarkan kajian permasalahan yang ada di kelas dan hasil pengamatan proses pembelajaran, peneliti mencoba menerapkan model pembelajaran teknik kepala bernomor untuk meningkatkan hasil belajar matematika siswa.Sebagaimana ditemukan sebelumnya, model pembelajaran kooperatif teknik kepala bernomor dapat meningkatkan kemandirian belajar siswa dan menuntut siswa aktif dalam proses 
pembelajaran (Bachtiar, et al, 2017; Qurniawati,et al, 2013). Melalui model pembelajaran kooperatif teknik kepala bernomor, siswa diharapkan dapat lebih bertanggung jawab pada dirinya dan kelompoknya. Selain itu diharapkan dengan adanya variasi proses pembelajaran, siswa dapat belajar lebih menyenangkan dan penuh semangat.

\section{METODE}

Penelitian ini merupakan penelitian tindakan kelas yang dilaksanakan di kelas X.5 SMAN 10 Pekanbaru pada tahun pelajaran 2015/2016 dengan subjek penelitian berjumlah 40 orang siswa.Penelitian ini terdiri dari 2 siklus.Setiap siklus meliputi prosedur penelitian tindakan berdasarkan Hopkins (2011) dengan tahapan seperti pada gambar 1.

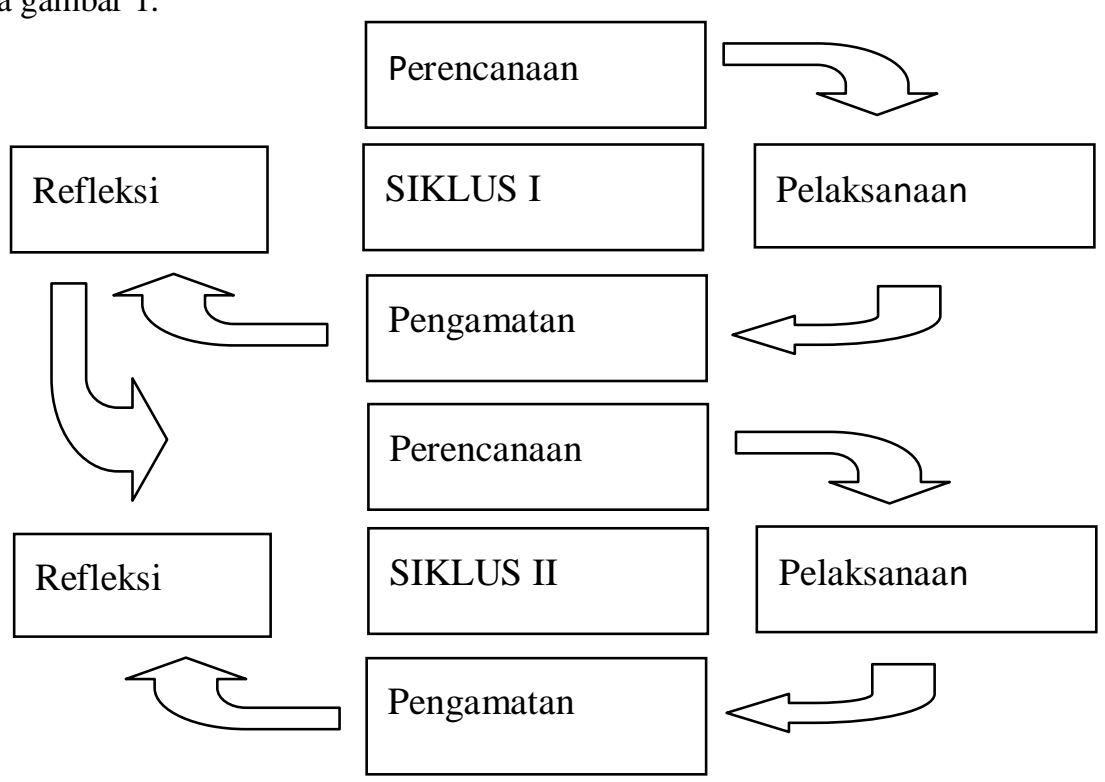

Gambar1. Siklus Penelitian Tindakan Kelas

Data pada penelitian ini dikumpulkan melalui tes tertulis di akhir setiap siklus, observasi proses pembelajaran dan wawancara siswa. Tes tertulis disusun berdasarkan tujuan dan kompetensi yang akan dicapai. Hal ini bertujuan untuk mengetahui pemahaman siswa secara kognitif pada topik pembahasan yang dibahas selama proses pembelajaran berlangsung. Soal yang diberikan pada tes tertulis merupakan soal pilihan ganda.

Setelah data dikumpulkan kemudian dianalisis. Data yang diperoleh merupakan hasil pengamatan/observasi aktifitas guru dan siswa selama proses belajar dan mengajar serta nilai tes tertulis yang diberikan pada setiap akhir siklus. Analisisis dilakukan terhadap hasil tes tersebut.Kategori ketuntasan belajar yang diharapkan adalah meningkatnya jumlah siswa yang mencapai KKM pada setiap siklus.Secara klasikal juga diharapkan persentase jumlah siswa yang mencapai KKM dapat lebih dari $75 \%$.Selain analisis nilai ketercapaian KKM juga dilakukan refleksi setelah selesai 1 siklus untuk memperbaiki kekurangankekurangan yang ada.Sehingga pada siklus berikutnya diperoleh hasil yang lebih baik.

\section{HASIL DAN PEMBAHASAN \\ Hasil Penelitian}

Sebagaimana disebutkan sebelumnya, penelitian ini terdiri dari 2 siklus dengan masing-masing siklus meliputi 4 tahapan sesuai Gambar 1.Pada tahap perencanaan awal (sebelum memulai siklus 1), peneliti menyiapkan perangkat pembelajaran yang diperlukan seperti lembar kerja siswa (LKS), lembar pengamatan, RPP, dan lainnya.Kemudian dilaksanakan siklus 1 dan 2 sesuai tahapan.

Proses pengamatan dilakukan bersamaan dengan jalannya proses pembelajaran. Setelah selesai satu siklus, kemudian diberikan tes tertulis kepada siswa untuk melihat ketercapaian KKM sebagai tolak ukur keberhasilan tindakan.Hasil tes tertulis pada siklus 1 dapat dilihat pada Tabel 1. 
Tabel 1. Rekapitulasi Hasil Tes Siklus 1

\begin{tabular}{ccc}
\hline No & Uraian & Hasil Siklus 1 \\
\hline $\mathbf{1}$ & Nilai rata-rata kelas & $\mathbf{6 8 , 2}$ \\
$\mathbf{2}$ & Jumlah siswa yang tuntas belajar & $\mathbf{2 1}$ \\
$\mathbf{3}$ & Persentase ketuntasan belajar & $\mathbf{5 2 , 5 0 \%}$ \\
\hline
\end{tabular}

Dari tabel 1 diperoleh databahwa nilai rata-rata kelas adalah 68,2. Kemudian 21 orang siswa dari total 40 siswa telah mencapai KKM.Jumlah ini meningkat dari sebelum dilaksanakan tindakan, yaitu 16 orang (40\%) mencapai KKM. Namun jumlah ini belum mencapai target keberhasilan tindakan yaitu 75\%.

Setelah selesai siklus 1, dilanjutkan dengan siklus 2. Pelaksanaan siklus 2 sama dengan siklus 1, yaitu pada kelas X.5 dengan jumlah siswa 40 orang. Guna terlaksananya siklus 2 dengan baik, maka peneliti memperbaiki beberapa hal dari siklus 1 yang merupakan hasil refleksi. Diantaranya adalah (1) perbaikan perangkat pembelajaran, (2) meningkatkan pengawasan guru dalam membimbing siswa berkelompok, (3) memperbaiki jalannya proses pembelajaran.

Pada akhir proses pembelajaran, siswa diberikan tes tertulis dengan tujuan melihat kembali apakah ada peningkatan pada nilai kognitif siswa. Hal ini merupakan tolak ukur apakah pelaksanaan siklus 2 lebih baik dari siklus 1.Hasil tes tertulis pada siklus 1 dapat dilihat pada Tabel 2.

Tabel 2. Rekapitulasi Hasil Tes Siklus 2

\begin{tabular}{ccc}
\hline No & Uraian & Hasil Siklus 2 \\
\hline $\mathbf{1}$ & Nilai rata-rata kelas & $\mathbf{8 3 , 7}$ \\
$\mathbf{2}$ & Jumlah siswa yang tuntas belajar & $\mathbf{3 1}$ \\
$\mathbf{3}$ & Persentase ketuntasan belajar & $\mathbf{7 7 , 5 0 \%}$ \\
\hline
\end{tabular}

Dari tabel 2 diperoleh databahwa nilai rata-rata kelas adalah 83,7. Kemudian 31 orang siswa dari total 40 siswa telah mencapai KKM.Jumlah ini meningkat dari sebelumnya (siklus 1), yaitu 21 orang (40\%) mencapai KKM.Jika dilihat dari persentase ketuntasan belajar, siklus 2 sudah memenuhi target yaitu 77,50\% siswa telah mencapai KKM. Target sebelum penelitian ini adalah $75 \%$.

Dengan berakhirnya siklus 2, maka berakhirlah rangkaian pelaksanaan tindakan.Meskipun begitu tetap dilakukan pengumpulan data dengan mewawancarai siswa terkait pelaksanaan pembelajaran menggunakan model kooperatif teknik kepala bernomor. Kemudian dilakukan refleksi tentang proses pembelajaran pada siklus 2 .

\section{Pembahasan}

Berdasarkan hasil penelitian diketahui bahwa proses pembelajaran telah mengikuti langkah-langkah pembelajaran model kooperatif teknik kepala bernomor yang telah ditetapkan sebelumnya. Pada tahap awal, guru menyiapkan perangkat pembelajaran sedemikian rupa, meliputi LKS, RPP, dan lembar pengamatan.Pada tahap pelaksanaan, guru semaksimal mungkin mengikuti alur model pembelajaran kooperatif teknik kepala bernomor. Guru mempersiapkan diri dengan cara membaca sebanyak mungkin literature terkait model pembelajaran serta mengawasi aktifitas siswa selama pembelajaran berlangsung. Siswa juga dikelompokkan dengan aturan model kooperatif teknik kepala bernomor.Ditemukan respon yang berbeda-beda dari setiap siswa tentang pengelompokkan ini.Meskipun demikian, siswa tetap berusaha menyelesaikan LKS sebaik mungkin.

Berdasarkan analisis aktivitas guru dan siswa selama penelitian, secara keseluruhan dapat dikatakan bahwa pelaksanaan pembelajaran sudah mendekati dengan yang direncanakan dalam RPP.Pada siklus 1, proses pembelajaran memang masih terdapat beberapa kelemahan yang dilakukan oleh peneliti dan siswa. Hal ini dapat dilihat dari aktivitas guru dan siswa selama proses pembelajaran. Pada siklus 1, siswa masih belum terbiasa dengan tahapan-tahapan pada proses Pembelajaran Kooperatif Teknik Kepala Bernomor. Tahap-tahap proses pembelajaran yang telah direncanakan juga belum terlaksana dengan baik. Masih terjadi pemborosan waktu untuk beberapa tahap pembelajaran, seperti pada saat mengorganisasikan siswa dalam kelompok. Akibatnya ada tahap yang tidak terlaksana pada proses pembelajaran.

Kekurangan pada pertemuan sebelumnya selalu diusahakan untuk diperbaiki pada pertemuan selanjutnya.Siswa juga sudah semakin terbiasa dengan model pembelajaran yang diterapkan oleh peneliti dan mulai terlibat aktif dalam diskusi kelompok. Kekurangan pada siklus 1 menjadi bahan perbaikan bagi peneliti 
untuk melaksanakan proses pembelajaran pada siklus 2. Pada proses pembelajaran di siklus 2, pelaksanaan tahapan-tahapan pembelajaran Kooperatif Teknik Kepala Bernomor telah berjalan semakin membaik pada setiap pertemuannya.

Berdasarkan hasil refleksi setelah selesai siklus 1, ditemukan beberapa kendala yang harus dihadapi selama proses pembelajaran, yaitu: (1) Guru dan siswa belum mengikuti alur model kooperatif teknik kepala bernomor dengan baik, hal ini dikarenakan teknik tersebut masih dirasa baru bagi guru dan siswa; (2) LKS belum memadai. Masih terdapat beberapa aspek yang menyulitkan siswa memahami materi pembelajaran.Sehingga siswa kesulitan mengkonstruk pengetahuannya terhadap materi; (3) Penggunaan waktu belum efisien. Karena teknik ini masih belum familiar oleh siswa, cukup banyak waktu terpakai untuk menjelaskan alur pembelajaran kepada siswa; (4) Kelompok siswa belum bekerja sama dengan baik. Ada kelompok yang hanya menyalin jawaban kelompok lain. Ada siswa yang hanya menunggu teman sekelompoknya menyelesaikan permasalahan.

Kendala yang ditemukan pada siklus 1 kemudian dicoba untuk diperbaiki agar siklus 2 dapat berjalan lebih baik dari siklus 1 dan mencapai target keberhasilan tindakan yang diinginkan. Adapun perbaikan yang dilakukan terhadap setiap kendala tersebut adalah: (1) Guru membaca kembali tentang alur model pembelajaran kooperatif teknik kepala bernomor dan lebih disiplin dalam mengikuti alur tersebut;(2) Guru memperbaiki LKS sedemikian sehingga LKS tersebut menjadi layak dan lebih baik dari sebelumnya. Perbaikan disini termasuk tatanan bahasa, penyampaian konsep materi, dan lain sebagainya; (3) Gurumerencanakan kembali pembagian waktu pembelajaran agar setiap alur pembelajaran dapat dilaksanakan dengan maksimal; (4) Guru memberikan pengertian kepada siswa, menghimbau siswa untuk lebih aktif dalam kelompoknya. Guru juga meningkatkan pengawasan/pengamatan kepada setiap anggota kelompok saatbekerjasama dengan kelompoknya.

Hasil penelitian menunjukkan adanya peningkatan hasil belajar siswa dengan menggunakan model pembelajaran kooperatif teknik kepala bernomor.Sebelum tindakan, persentase ketuntasan belajar siswa adalah $40 \%$. Setelah selesai siklus 1 diperoleh persentase ketuntasan belajar siswa adalah 52,5\%. Kemudian pada siklus 2 diperoleh persentase ketuntasan belajar siswa adalah 77,5\%. Jumlah ini sudah memenuhi kriteria keberhasilan tindakan yaitu 75\% siswa mencapai KKM.Hal ini sejalan dengan hasil penelitian oleh Rafiqah (2018), Hayati (2012), Tivany, Abdurachman\& Hartono (2016) yang menemukan bahwa model kooperatif teknik kepala bernomor dapat meningkatkan hasil belajar siswa. Selain itu model pembelajaran kooperatif teknik kepala bernomor dapat meningkatkan keaktifan belajar siswa.

\section{SIMPULAN}

Berdasarkan hasil penelitian dan pembahasan dapat disimpulkan bahwa penerapan model pembelajaran kooperatif teknik kepala bernomor dapat meningkatkan hasil belajar siswa dengan persentase pada siklus 1 sebesar 52,5\% siswa mencapai KKM, dan siklus 2 sebesar 77,5\% siswa mencapai KKM. Jumlah ini sudah memenuhi kriteria keberhasilan tindakan yaitu 75\%.Namun perlu ditingkatkan lagi.Semakin tinggi persentase ketercapaian KKM berarti semakin baik hasil belajar siswa.Untuk mencapai ini, guru perlu mempertimbangkan menggunakan variasi model-model pembelajaran lainnya.Atau guru dapat meneruskan menggunakan model kooperatif teknik kepala bernomor dengan melanjutkan ke siklus 3 dan seterusnya.

Model pembelajaran kooperatif teknik kepala bernomor dapat dijadikan salah satu solusi untuk meningkatkan hasil belajar siswa. Selain hasil belajar siswa, guru dapat mencoba meningkatkan aspek lain pada diri siswa menggunakan model ini. Hasil penelitian ini hanya menjelaskan aspek kognitif dari hasil belajar.Oleh karena itu hasil penelitian ini dapat dijadikan landasan untuk mencoba aspek afektif dan psikomotor dari hasil belajar siswa.

\section{REFERENSI}

Arends, R.I., \& Kilcher, A. (2010). Teaching for student learning: Becoming an accomplished teacher.New York: Taylor \& Francis e-library.

Bachtiar, B., Wahyuningsih, E. D., \& Susongko, P. (2017).Keefektifan Model Pembelajaran NHT Tipe Kepala Bernomor Struktur Berbantu CD Pembelajaran Ditinjau Dari Konsep Diri Terhadap Prestasi Belajar Matematika. JPMP (Jurnal Pendidikan MIPA Pancasakti), 1(1).

Hayati, Y. (2012). Inovasi Perkuliahan Sejarah Sastra Indonesia dengan Menggunakan Metode Diskusi Kelompok Model Kepala Bernomor. Komposisi: Jurnal Pendidikan Bahasa, Sastra, Dan Seni, 11(1).

Hopkins, D. (2011). Penelitian Tindakan Kelas. Yogyakarta: Pustaka Pelajar. 
Lie, A. (2010). Mempraktikkan Cooperative Learning di Ruang-Ruang Kelas. Jakarta:Grasindo

Molstad, C. E., \& Karseth, B. (2016). National Curricula in Norway and Finland: The Role of Learning Outcomes. European Educational Research Journal, 15 (3), 329-344

Qurniawati, A., Sugiharto, S., Saputro, C., \& Nugroho, A. (2013). Efektivitas Metode Pembelajaran Kooperatif Tipe Numbered Head Together (Nht) Dengan Media Kartu Pintar Dan Kartu Soal Terhadap Prestasi Belajar Siswa Pada Materi Pokok Hidrokarbon Kelas X Semester Genap SMA Negeri 8 Surakarta. Jurnal Pendidikan Kimia Universitas Sebelas Maret, 2(3), 166-174.

Rafiqah, R. (2018). Efektivitas Penerapan Model Pembelajaran Kooperatif Tipe Kepala Bernomor Struktur Terhadap Peningkatan Hasil Belajar. Jurnal Pendidikan Fisika, 6(2), 110-113.

Rusman. (2012). Model-model pembelajaran mengembangkan profesional guru.Jakarta : Raja Grafindo Persada

Slameto. (2003). Belajar dan Faktor-Faktor yang Mempengaruhinya. Jakarta: Rineka Cipta.

Slavin, R, E. (1995). Cooperative Learning Theory.Second Edition. Massachusetyts: Allyn and Bacon Publisher

Tivany, F., Abdurachman, F., \& Hartono, M. (2016). Penerapan Model Pembelajaran Kepala Bernomor Terstruktur Untuk Meningkatkan Hasil Belajar Kimia Siswa. Jurnal Pengajaran MIPA, 21(1), $42-45$.

Trianto. (2007). Model-Model Pembelajaran Inovatif Berorientasi Konstruktif. Jakarta: Prestasi Pustaka.

Warsita, Bambang.2008. Teknologi pembelajaran landasan dan aplikasinya.Jakarta: Rineka Cipta 